\title{
Color ruler to confirm spectrophotometer results for nitro compound content in acidic wastewater from TNT processes
}

\author{
Ahmed Mahjoub Osman*, Osman Ali Osman Eltayeb* \\ * Defence Industrial System, AIC, Khartoum, Sudan \\ Email: aahmedmahjoop@gmail.com
}

\begin{abstract}
This study aimed to find an additional analytical reference procedure to verify the accuracy of single beam Spectrophotometer results that used to determine the concentration of nitro compound pollutants such as TNT, DNT, and MNT (Tri Nitro Toluene, Di Nitro toluene, and Mono Nitro Toluene respectively) in treated acidic wastewater generated from TNT manufacturing. This procedure was tested and confirmed to be a reference for a single-beam spectrophotometer. In this study 10 samples with known concentrations were taken and prepared for colorimetric analysis, the concentrations gradient from $10 \mathrm{mg} / \mathrm{L} \mathrm{up} \mathrm{to} 60 \mathrm{mg} / \mathrm{L}$ to $\mathrm{make}$ a ruler with gradient color, this ruler was suitable for high concentration samples but to specify the low concentration samples the procedure depended on adding a known concentration to the unknown concentration sample then this added concentration transferred the samples from unspecified color to specified color on the ruler consisted by known concentration mentioned above, the concentration of unknown concentration samples were specified by taking the concentration corresponding to the ruler color a subtracting the value of added concentration and the value of the remains was sample concentration. This study proved the reliability of this procedure to confirm single-beam spectrophotometer results, determining low concentration value of unknown concentration sample of TNT acidic wastewater, and then it can be used as a substituent of spectrophotometer in the event of malfunctions.
\end{abstract}

Key words-Spectrophotometer, Pollutant, Wastewater, Single beam, Acidic

\section{INTRODUCTION}

Generally, chemical analysis is used to identify and quantify the elements and compounds for matters even that these matters are organic or non-organic. Chemical analysis can be classified or grouped by different methods, one of these groups divide the chemical analysis into four categories, which are:

\section{A. Qualitative analysis}

Identifies the species that present in sample.

\section{B. Quantitative analysis}

Determine the amount of species in the sample.

\section{Structural analysis}

Focusing on molecular and the arrangement of atoms, function groups and chemical ponding presence in the molecular.

\section{Surface analysis}

Which study the physical properties and chemical phenomenon that happened to phases at matters [1], [2]. The use of instruments in chemical analysis has become of vary wide range to facilitate for ease of work, and it can also be used for many different types of analysis especially in the analysis of hazardous material to confirm treat method are in the right way, one of these important instruments is Spector-photometer see Fig. 1, this device depends on absorptivity of light by different solutions as in Fig. 2 that shoes mechanism of device working theory.

Most researches in the determination of (TNT, DNT) in wastewater focusing on getting proven and correct results by developing the apparatus. For testing the samples cells in Fig. 1 below were used.

\section{Statement of Problem}

In wastewater treatment, we always need to make sure that the treated wastewater result is accurate, because of the risk that will arise from pollutants (mono, dinitro toluene, and trinitrotoluene) and the potential impact on the environment, for this reason, and some problems for spectrophotometer during production there should be a spare device or think of A new way to check the accuracy of results to guarantee the specifications of treated TNT acidic wastewater.

\section{Methodology}

Spectrophotometer Method was used to determine TNT acidic wastewater pollutant concentrations in this study.

\section{A. principles of spectrophotometer}

Spectrophotometer depends on its work on measuring the absorbance of light falling on the sample, the concentration of the sample calculated using the mathematical relationship between the amounts of absorbed light with a concentration of the substance according to the law of two scientists Beer \& Lambert [1], [2]. 


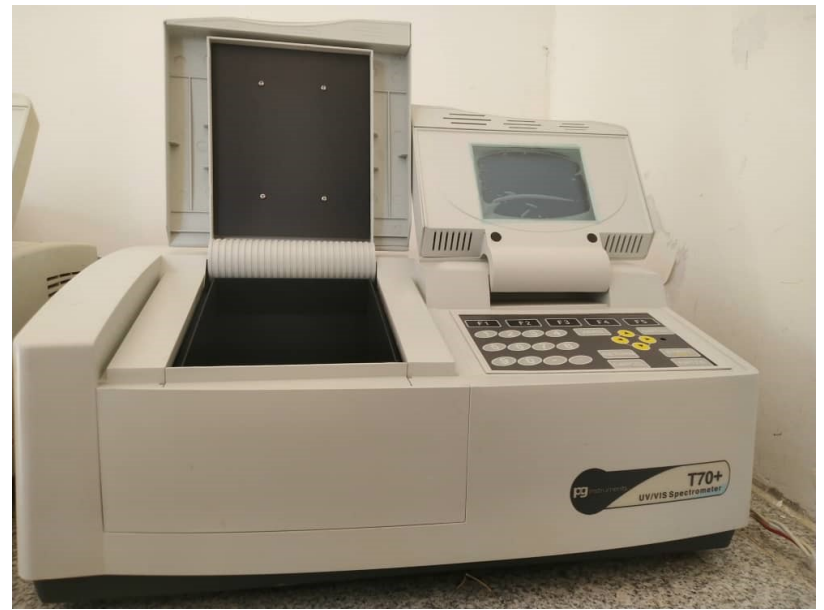

Fig. 1. Single Beam Spectrophotometer

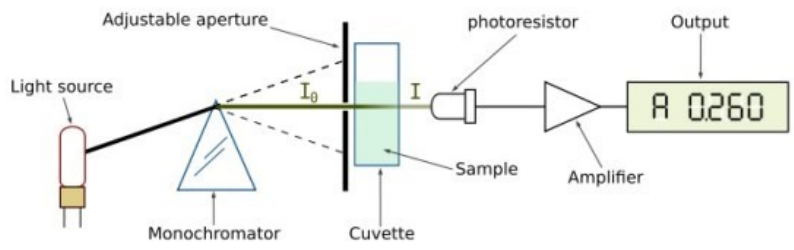

Fig. 2. Single Beam Spectrophotometer working principle

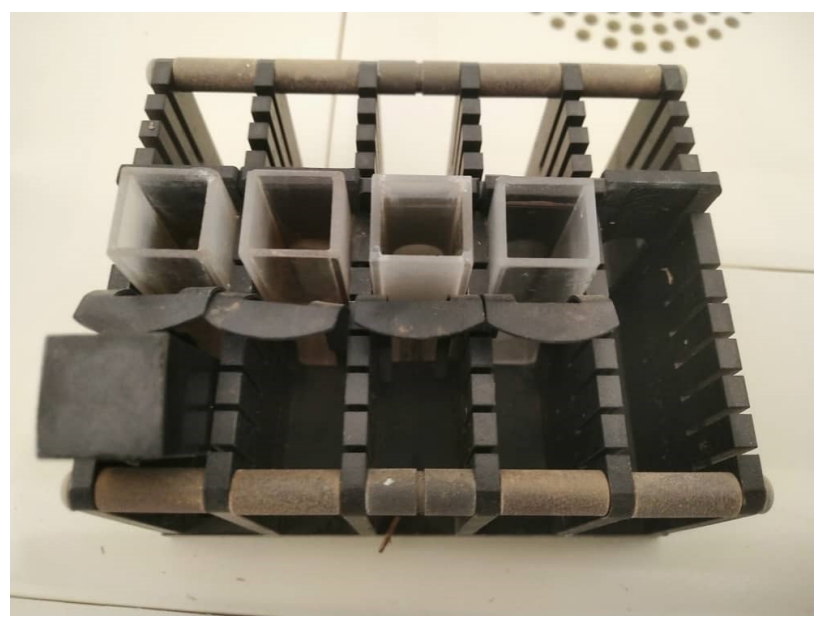

Fig. 3. Test cells for apparatus spectrophotometer

$$
A=\epsilon l c
$$

To find and calculate factor used to determine the concentration of pollutant in samples by measuring the absorbance of the colored solution by spectrophotometer, we firstly prepare standard concentration of pollutant and extract the value from it with mathematical equations as below.

1) Prepare a standard solution with different concentrations of pollutants and read absorption value with a spectrophotometer and result was obtained in TABLE I [3].

2) Use the statistical equation and data in TABLE I to find factor and correlation coefficient by regression and correlation equations below [4].

$$
y=b x+a
$$

$$
b=\sum_{n}^{i-1}\left(x_{i}-x\right)\left(y_{i}-y\right) / \sum_{n}^{i-1}\left(x_{i}-x\right)^{2}
$$

$$
r^{2}=\sum_{n}^{i-1}\left(x_{i}-x\right)\left(y_{i}-y\right) / \sqrt{\left(\sum_{n}^{i-1}\left(x_{i}-x\right)^{2}\right.} \cdot \sqrt{\left(\sum_{n}^{i-1}\left(y_{i}-y\right)^{2}\right.}
$$

\section{B. Determination of mono, dinitro compound by Single beam Spectrophotometer}

The principle of the method, in an acidic solution containing nitro compound adding of copper sulfate, zinc powder will react with the acid in the sample to form nascent hydrogen, which reduces nitrobenzene into aniline to make purplish red dye. Based on the fact nitro compounds can be determined by spectrophotometer [3], [5].

\section{Determination of tri nitro compound by single beam Spec- trophotometer}

In an acidic solution containing nitro compounds adding of sodium sulfate, chlorhexadecypyridine (CPC) ethyl amino methane (DEAG) solution, the main tri nitro compound such as 2,4,6,-trinitro toluene (TNT) and 2,4,6 tri nitro benzoic acid (-TNB) form a sensitive colored compound which can be determined by spectrophotometer [3], [5].

\section{Color ruler}

The objectives of this color ruler are to prepare color for the color comparison without using a spectrophotometer apparatus by mean visible test for instant results for TNT acidic wastewater and the tested with spectrophotometer to confirm results to guarantee dependability of the colorimetric ruler, for this ruler the steps below were flowed:

1) Prepare 10 sample (two set MNT, DNT and TNT) with different concentration gradient $(10 \mathrm{mg} / 1,20 \mathrm{mg} / \mathrm{l}$, $30 \mathrm{mg} / 1, \quad 40 \mathrm{mg} / 1, \quad 50 \mathrm{mg} / 1, \quad 60 \mathrm{mg} / 1, \quad 70 \mathrm{mg} / 1, \quad 80 \mathrm{mg} / 1$, $90 \mathrm{mg} / 1$, and $100 \mathrm{mg} / \mathrm{l}$ ) from TNT standard solution, the color on tube differentiate from light color to dark with concentration (orange color) same as above [3].

2) Prepare the wastewater sample according to procedure with additive same as the way used in 3.2 and 3.3 above.

3) Comparer the wastewater tube with standard colored tubes to find matched color.

4) If the color match one of the standard tube, which means this is the concentration of the wastewater sample.

5) If the color fall between two gradients of the color ruler (for example between $80 \mathrm{mg} / 1$ and $90 \mathrm{mg} / \mathrm{l}$ ), then we create more accurate color ruler by more specific concentration from standard solution $(81 \mathrm{mg} / \mathrm{l}, 82 \mathrm{mg} / \mathrm{l}$, $83 \mathrm{mg} / \mathrm{l}, 84 \mathrm{mg} / \mathrm{l}, 85 \mathrm{mg} / \mathrm{l}, 86 \mathrm{mg} / \mathrm{l}, 87 \mathrm{mg} / 1,88 \mathrm{mg} / \mathrm{l}$, and $89 \mathrm{mg} / 1)$. 
6) Normally all concentrations from the input stream of the section are high and no need to have an accurate number of concentrations of pollutant.

7) For the output stream (treated water) we need accurate reading of pollutant concentration, we prepare another color ruler in small concentration $(1 \mathrm{mg} / \mathrm{l}, 2 \mathrm{mg} / \mathrm{l}, 3 \mathrm{mg} / \mathrm{l}$, $4 \mathrm{mg} / \mathrm{l}, 5 \mathrm{mg} / \mathrm{l}, 6 \mathrm{mg} / \mathrm{l}, 6 \mathrm{mg} / \mathrm{l}, 7 \mathrm{mg}, / 1,8 \mathrm{mg} / \mathrm{land} 9 \mathrm{mg} / \mathrm{l})$ which we called it Guba ruler.

8) In a $10 \mathrm{ml}$ test tube we put the treated pollutant sample and then start to add from the Guba ruler one by one until the color match tube contain $10 \mathrm{mg} / \mathrm{l}$ color, then we discount the concentration value of the ruler from $10 \mathrm{mg} / \mathrm{l}$ to give us the sample concentration according to the equation below:

$$
S=10-G
$$

Where: S: treated pollutant sample (mg/l) G: concentration of gradient in Guba ruler $\mathrm{mg} / \mathrm{l} 10$ : refer to concentration in color ruler $\mathrm{mg} / \mathrm{l}$

\section{RESUlts}

Samples were taken for the TNT acidic wastewater treatment section to determine the nitro compound ( $\alpha$ - TNT \&TNB) in both income and outcome stream of the section and results below was obtained in the tables below.

TABLE I

ABSORPTION RESULTS FOR STANDARD SOLUTIONS

\begin{tabular}{lll}
\hline Sample No & Sample Concentration $\mathrm{mg} / \mathrm{l}$ & $\mathrm{ABs}$ \\
\hline 1 & 0.0000 & 0.006 \\
2 & 5.000 & 0.046 \\
3 & 10.000 & 0.080 \\
4 & 15.000 & 0.124 \\
5 & 20.000 & 0.166 \\
6 & 25.000 & 0205 \\
\hline
\end{tabular}

TABLE II

MNT, DNT RESULT FOR ACIDIC WASTEWATER TESTED ON 19 DEC 2019

\begin{tabular}{llll}
\hline Sample & ABs & Concentration & Position \\
\hline Blank & 0.000 & $0.00 \mathrm{mg} / \mathrm{l}$ & - \\
$1 \mathrm{ml}$ & 0.080 & $10 \mathrm{mg} / \mathrm{l}$ & Raw waste water (In) \\
$3 \mathrm{ml}$ & 0.018 & $2.25 \mathrm{mg} / \mathrm{l}$ & Treated waste water (out) \\
$1 \mathrm{ml}$ & 0.080 & $10 \mathrm{mg} / \mathrm{l}$ & Raw waste water (In) \\
$3 \mathrm{ml}$ & 0.015 & $1.87 \mathrm{mg} / \mathrm{l}$ & Treated waste water (out) \\
\hline
\end{tabular}

TABLE III

MNT, DNT RESULT FOR ACIDIC WASTEWATER TESTED ON 21 DEC 2019

\begin{tabular}{llll}
\hline Sample & ABs & Concentration & Position \\
\hline Blank & 0.000 & $0.00 \mathrm{mg} / \mathrm{l}$ & - \\
$1 \mathrm{ml}$ & 0.081 & $10 \mathrm{mg} / \mathrm{l}$ & Raw waste water (In) \\
$3 \mathrm{ml}$ & 0.012 & $1.5 \mathrm{mg} / \mathrm{l}$ & Treated waste water (out) \\
$1 \mathrm{ml}$ & 0.086 & $10.75 \mathrm{mg} / 1$ & Raw waste water (In) \\
$3 \mathrm{ml}$ & 0.011 & $1.5 \mathrm{mg} / \mathrm{l}$ & Treated waste water (out) \\
\hline
\end{tabular}

TABLE IV

MNT, DNT RESULT FOR ACIDIC WASTEWATER TESTED ON 25 DEC 2019

\begin{tabular}{llll}
\hline Sample & ABs & Concentration & Position \\
\hline Blank & 0.000 & $0.00 \mathrm{mg} / \mathrm{l}$ & - \\
$1 \mathrm{ml}$ & 0.099 & $12.38 \mathrm{mg} / 1$ & Raw waste water (In) \\
$3 \mathrm{ml}$ & 0.020 & $2.5 \mathrm{mg} / \mathrm{l}$ & Treated waste water (out) \\
$1 \mathrm{ml}$ & 0.101 & $12.62 \mathrm{mg} / 1$ & Raw waste water (In) \\
$3 \mathrm{ml}$ & 0.022 & $2.75 \mathrm{mg} / \mathrm{l}$ & Treated waste water (out) \\
\hline
\end{tabular}

TABLE V

MNT, DNT RESULT FOR ACIDIC WASTEWATER TESTED ON 21 JAN 2020

\begin{tabular}{llll}
\hline Sample & ABs & Concentration & Position \\
\hline Blank & 0.000 & $0.00 \mathrm{mg} / \mathrm{l}$ & - \\
$1 \mathrm{ml}$ & 0.089 & $11.13 \mathrm{mg} / \mathrm{l}$ & Raw waste water $(\mathrm{In})$ \\
$3 \mathrm{ml}$ & 0.019 & $2.37 \mathrm{mg} / \mathrm{l}$ & Treated waste water (out) \\
$1 \mathrm{ml}$ & 0.087 & $10.88 \mathrm{mg} / \mathrm{l}$ & Raw waste water (In) \\
$3 \mathrm{ml}$ & 0.018 & $2.25 \mathrm{mg} / \mathrm{l}$ & Treated waste water (out) \\
\hline
\end{tabular}

TABLE VI

TNT RESULT FOR ACIDIC WASTEWATER TESTED ON 19 DEC 2019

\begin{tabular}{llll}
\hline Sample & ABs & Concentration & Position \\
\hline Blank & 0.000 & $0.00 \mathrm{mg} / \mathrm{l}$ & - \\
$1 \mathrm{ml}$ & 0.163 & $20.38 \mathrm{mg} / \mathrm{l}$ & Raw waste water (In) \\
$3 \mathrm{ml}$ & 0.023 & $2.87 \mathrm{mg} / \mathrm{l}$ & Treated waste water (out) \\
$1 \mathrm{ml}$ & 0.158 & $19.76 \mathrm{mg} / \mathrm{l}$ & Raw waste water (In) \\
$3 \mathrm{ml}$ & 0.028 & $3.50 \mathrm{mg} / \mathrm{l}$ & Treated waste water (out) \\
\hline
\end{tabular}

TABLE VII

TNT RESULT FOR ACIDIC WASTEWATER TESTED ON 21 DEC 2019

\begin{tabular}{llll}
\hline Sample & ABs & Concentration & Position \\
\hline Blank & 0.000 & $0.00 \mathrm{mg} / \mathrm{l}$ & - \\
$1 \mathrm{ml}$ & 0.159 & $19.76 \mathrm{mg} / \mathrm{l}$ & Raw waste water (In) \\
$3 \mathrm{ml}$ & 0.027 & $3.50 \mathrm{mg} / \mathrm{l}$ & Treated waste water (out) \\
$1 \mathrm{ml}$ & 0.168 & $21.01 \mathrm{mg} / \mathrm{l}$ & Raw waste water (In) \\
$3 \mathrm{ml}$ & 0.030 & $3.75 \mathrm{mg} / \mathrm{l}$ & Treated waste water (out) \\
\hline
\end{tabular}

TABLE VIII

TNT RESULT FOR ACIDIC WASTEWATER TESTED ON 25 DEC 2019

\begin{tabular}{llll}
\hline Sample & ABs & Concentration & Position \\
\hline Blank & 0.000 & $0.00 \mathrm{mg} / \mathrm{l}$ & - \\
$1 \mathrm{ml}$ & 0.159 & $19.76 \mathrm{mg} / \mathrm{l}$ & Raw waste water (In) \\
$3 \mathrm{ml}$ & 0.027 & $3.50 \mathrm{mg} / \mathrm{l}$ & Treated waste water (out) \\
$1 \mathrm{ml}$ & 0.168 & $21.01 \mathrm{mg} / \mathrm{l}$ & Raw waste water (In) \\
$3 \mathrm{ml}$ & 0.030 & $3.75 \mathrm{mg} / \mathrm{l}$ & Treated waste water (out) \\
\hline
\end{tabular}

TABLE IX

TNT RESULT FOR ACIDIC WASTEWATER TESTED ON 25 DEC 2019

\begin{tabular}{llll}
\hline Sample & ABs & Concentration & Position \\
\hline Blank & 0.000 & $0.00 \mathrm{mg} / \mathrm{l}$ & - \\
$1 \mathrm{ml}$ & 0.181 & $22.64 \mathrm{mg} / 1$ & Raw waste water (In) \\
$3 \mathrm{ml}$ & 0.045 & $5.62 \mathrm{mg} / 1$ & Treated waste water (out) \\
$1 \mathrm{ml}$ & 0.185 & $23.14 \mathrm{mg} / 1$ & Raw waste water (In) \\
$3 \mathrm{ml}$ & 0.048 & $6 \mathrm{mg} / \mathrm{l}$ & Treated waste water (out) \\
\hline
\end{tabular}


These results in the above tables shows the values of the test result by the spectrophotometer and the results obtained by using the color ruler are same; but observed that color ruler cannot measure values of concentration $; 1 \mathrm{mg} / 1$ (fractions)and it is just fit for only integer number e.g $(1,2,) \mathrm{mg} / \mathrm{l}$.

\section{CONCLUSION}

This procedure is simple and effective to use in the same time with spectrophotometer apparatus to confirm results or alone as new procedure and the accuracy of it depend on preparing accurate standard solution and analyst skills. To improve this procedure, it is better to manufacture a paper ruler contain the color gradients and just compare the sample with it same as PH papers.

\section{RECOMMENDATIONS}

1) Further studies must be done for making nomogram to confirm results obtained by spectrophotometer apparatus and used as other options for analysis.

2) this study done for TNT acidic wastewater, so we recommended other study conducted for other wastewater with hazardous pollutants.

3) We recommended conducting more studies for this coulometric ruler method to address the shortcoming that represented its inability of it to measure concentration values ; $1 \mathrm{mg} / \mathrm{l}$.

\section{REFERENCES}

[1] R. Khandpur, "Handbook of analatical instruments," Third Edition, vol. 13, pp. 9789339221355,

[2] T. E. Jacke Caze, EWINGS ANALYTICAL INSTRUMENTATION HANDBOOK.

[3] S. PROJECT, "Determination of tnt waste water composition,2007."

[4] R. E. Walpole, R. H. Myers., S. L. Myers, and K. Ye. Probability \& Statistics for Engineers \&Scientist.

[5] Norinco, "Technical traning textbook of sudan chemical industry project." 